\title{
Overburden Thickness and Potential Tonnage Estimate of Olode-Gbayo Pegmatite Deposit, Southwestern Nigeria, Using Electrical Resistivity Method
}

\author{
Lukuman Abudulawal $^{1^{*}}$, Sikiru Adetona Amidu ${ }^{2,3 \#}$, Olusola Ayoade Adeagbo ${ }^{1}$ \\ and Saheed Adesanjo Adejumo ${ }^{1}$ \\ ${ }^{1}$ Department of Geology, The Polytechnic, Ibadan, Oyo State, Nigeria. \\ ${ }^{2}$ Department of Geosciences, Baylor University, Waco, Texas, USA. \\ ${ }^{3}$ Mobil Producing Nigeria Unlimited, 1 Lekki Expressway, Victoria Island, Lagos, Nigeria.
}

Authors' contributions

This work was carried out in collaboration between all authors. All authors read and approved the final manuscript.

Article Information

DOI: 10.9734/JGEESI/2017/32811

Editor(s):

(1) Ioannis K. Oikonomopoulos, Core Laboratories L.P., Petroleum Services Division, Houston Texas, USA.

Reviewers:

(1) G.W.A. Rohan Fernando, The Open University of Sri Lanka, Sri Lanka. (2) Nguyen Ba Dai, Kunming University of Science and Technology, Kunming, China.

(3) Ahmad Helman Hamdani, University Padjadjaran, Indonesia. (4) Mohamed Ahmed El-Sadek, Nuclear Materials Authority, Egypt. Complete Peer review History: http://www.sciencedomain.org/review-history/19131

Original Research Article

Received $16^{\text {th }}$ March 2017 Accepted $12^{\text {th }}$ May 2017 Published $18^{\text {th }}$ May 2017

\section{ABSTRACT}

Prominent locations in the Nigerian basement complex are known to harbor precious rocks and gemstones, in addition to the basement rocks being quarried for engineering construction. However, reserve estimates of these rocks and mineral deposits are largely unknown. Geophysical investigations have been undertaken at Olode-Gbayo village in Ibadan, southwestern, Nigeria. The primary objectives are to estimate overburden thickness and extend results to estimate probable gross basement tonnage and probable reserve of mineralized pegmatite in the basement rock. The Olode-Gbayo pegmatite has been found to be mineralized in aquamarine at depths. A total of seventeen vertical electrical soundings (VES) were carried out. Data acquisition involved the use of 
Schlumberger electrode configuration. Interpretation of the geoelectrical data involved the use of curve matching technique and computer iteration. Geoelectrical cross sections and isopach maps were constructed based on lateral combination of inverted soundings from the VES surveys. Existing mining pits were logged and rock samples were collected to estimate basement rock distribution and determine specific rock gravity. The VES result showed a three to four geo-electric layers, the top soil, weathered layer, partially weathered layer and fresh or partially fractured basement. Overburden thickness varied from about 2.6 to about $7.7 \mathrm{~m}$. The thickest overburden is observed in the southern part whereas thinner overburden is observed in the northern part of the area. Using an exploitable basement rock thickness of $50 \mathrm{~m}$, gross basement rock tonnage was estimated as $1.95 \times 10^{8}$ tons, with pegmatite being estimated to constitute about $0.5 \%$ of the basement rock volume. Generally, the basement rock is considered economically viable for mining and engineering construction, whereas the pegmatite rocks could be economically minable as host rock for gemstone.

Keywords: Overburden thickness; potential tonnage; pegmatite; basement complex; electrical resistivity; southwestern Nigeria.

\section{INTRODUCTION}

Approximately $50 \%$ of Nigerian landmass is geologically underlain by crystalline basement rocks. These basement rocks have been found to host various precious metallic and non-metallic minerals $[1,2,3]$ and potential target for groundwater $[4,5,6,7]$. In addition, the basement rocks are mined in several locations as source of construction materials $[3,8]$. The current national drive towards breaking the much dependence of Nigerian economy on oil has identified the need to develop solid minerals and rocks as alternate sources of income to the government. Consequently, key reforms were carried out, in recent time, to build both institutional and infrastructural capacity within government agencies to provide necessary geo-scientific support required to attract new private sector investment into the sector [9]. One key challenge is lack of accurate data on the tonnage of rock and mineral deposits, which in turn, accounts for high prevalence of illegal mining activities. As at 2003, one conservative estimate showed over 20 tons of different mineral grades had been mined all over the country generating millions of dollars to individuals, with little returns to the government [1].

Estimating reserve and tonnage of mineral resources is a highly methodical process and has been the focus of various discussions $[10,11]$. If the exploration of a possible deposit is well advanced, one can work with geostatistical methods, which take the spatial interdependence of drill-hole data into account and are certainly the best way to arrive at the most reliable input data. However, as shown by [11], at an early exploration stage sufficiently large database is not available and geologist has only a tentative idea about expected grades and tonnages based on the initial geological concept and early concrete indications through observations from trenches or a limited number of drill holes. Generally, at this early stage, other cruder methods have to be applied to arrive at approximate estimates of potential grade and tonnage [11]. These early ideas about grades and tonnages have been tagged by the authors as grade and tonnage potentials, respectively. The present study falls into these latter approaches.

Olode-Gbayo is one of the known quarrying and gemstone mining locations in the country. Whereas the bulk basement rocks are being quarried for construction materials; pegmatite is being mined as host rock for gemstone. The gemstone, mostly aquamarine, has been classified as high grade and occurs within the pegmatite bodies in the basement complex [1]. Currently, main production from the study area comes from artisanal mining (Fig. 1) which is mostly non-systematic due to a lack of detailed geological and geophysical information.

In this study, we carried out geophysical survey and field mapping, to estimate overburden thickness and extend results for estimation of possible tonnage potential of the basement rocks in Olode-Gbayo, southwestern Nigeria. The geophysical survey involved vertical electrical sounding (VES), which is based on response of the earth to the flow of electrical current [12]. The method has been extensively used for mineral exploration [13] as well as groundwater exploration $[5,6,7]$ and pollution mapping [14, 15]. Also, its use for depth estimation to aid in 


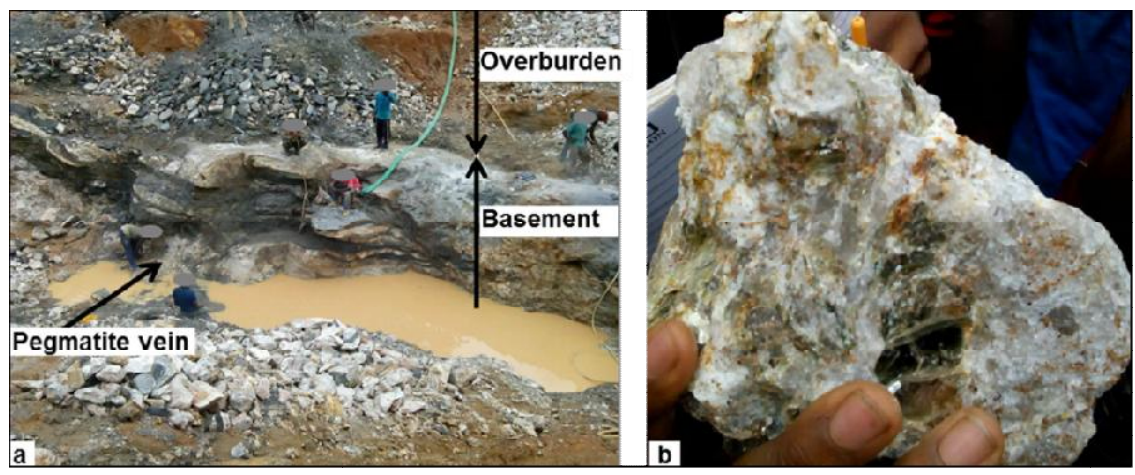

Fig. 1. (a) Example of mining pits showing active artisanal mining at the study site; (b) Pegmatite rock sample

reserve estimation of varying sedimentary and lateritic deposits has been demonstrated $[16,17]$. Although, VES provides one-dimensional measure of electrical resistivity variations in the subsurface, effective characterization of basement geology has been reported using this method $[5,6,7,18]$. The field mapping involves visual observation of outcrops and description of lithological profiles in mining pits in the area. Special consideration was given to macrotextural structures. The VES enabled estimation of overburden thickness, and results were used alongside field observation to generate parameters for estimating probable reserve and tonnage potential of the rocks. The results, though a rough estimate, are expected to be useful in overall assessment of the quarry site and in effective management of mining activities in Olode-Gbayo area and beyond.

\section{MATERIALS AND METHODS}

\subsection{Description of the Study Area}

The study area is a village in Oluyole Local Government area in Ibadan, southwestern Nigeria. It falls within Latitudes $07^{\circ} 11^{\prime} \mathrm{N}$ and $07^{\circ} 13^{\prime} \mathrm{N}$, and Longitudes $03^{\circ} 55^{\prime} \mathrm{E}$ and $03^{\circ} 57^{\prime} \mathrm{E}$ (Fig. 2). The study area is generally accessible as availability of both tarred and un-tarred roads as well as footpaths provides good accessibility to the area. The area lies within the humid and sub-humid climate region with mean annual rainfall of about $1230 \mathrm{~mm}$ and mean maximum temperature of $32^{\circ} \mathrm{C}$. The area is drained by network of streams and general drainage pattern is dendritic.

Geologically, the study area lies within the Nigerian basement complex characterized by crystalline rocks of Pre-Cambrian age [19]. Local geological mapping shows that the major crystalline rocks in the study area include: Biotite granite; migmatite gneiss and undifferentiated gneiss complex (Fig. 3). The major rock that dominates the area investigated is the undifferentiated gneiss complex and is easily recognized by their characteristic alternating parallel light and dark coloured bands with mesocratic outlook. Mineralogically, the light bands consist essentially of quartz (identified by its vitreous luster, anhedral form and colourless nature) and feldspar (identified by its whitish colour and cleavage in well-formed crystals). The dark band is made up essentially of biotite which is easily identified because of its dark colour, sheen, flaky nature and platy habit. The migmatite gneiss which is about $20 \%$ of the area is believed to have resulted from complex association of deformation, shearing and folding, granitization and migmatization processes [19]. It comprises of gneisses, quartzites, calc-silicate rocks, biotite-hornblende schist and amphibolites. The biotite granite which is about $10 \%$ of the area is easily identified because of its black colour, sheen, flaky nature and platy habit.

Prominent locations, mostly in the southwestern and northern part of Nigeria, are known to harbor precious rocks and gemstones, in which important host rocks are pegmatites [1,2]. The gemstone occurrences are found within N-S, NESW trending pegmatites veins, which are sometimes vertical or steeply dipping. These veins intrude older lithologies of the migmatite gneiss complex rocks, mafic-ultramafic units, and schistose rock. The pegmatites are in most cases strongly foliated, intruded weak zones and vary considerably in sizes from about $5 \mathrm{~m}$ up to sometime 2 kilometers along the strike [1]. Olode-Gbayo, is one of the known gemstone 
mining locations in the country, and the gemstone has been found to be high grade aquamarine. The pegmatite veins occur as dykes with low dip and strike in the NNE-SSW direction [2]. The gemstone, aquamarine, occurs as discrete crystals embedded as anhedral shaped crystals within the pegmatite (Fig. 1b). They range in colour from sky-blue to green.

\subsection{Data Acquisition}

\subsubsection{Electrical resistivity survey}

Seventeen Schlumberger vertical electrical soundings (VES) were made in the study area using a maximum spread (AB) of $200 \mathrm{~m}$. The data was collected by 4-person team using a digital averaging equipment as the

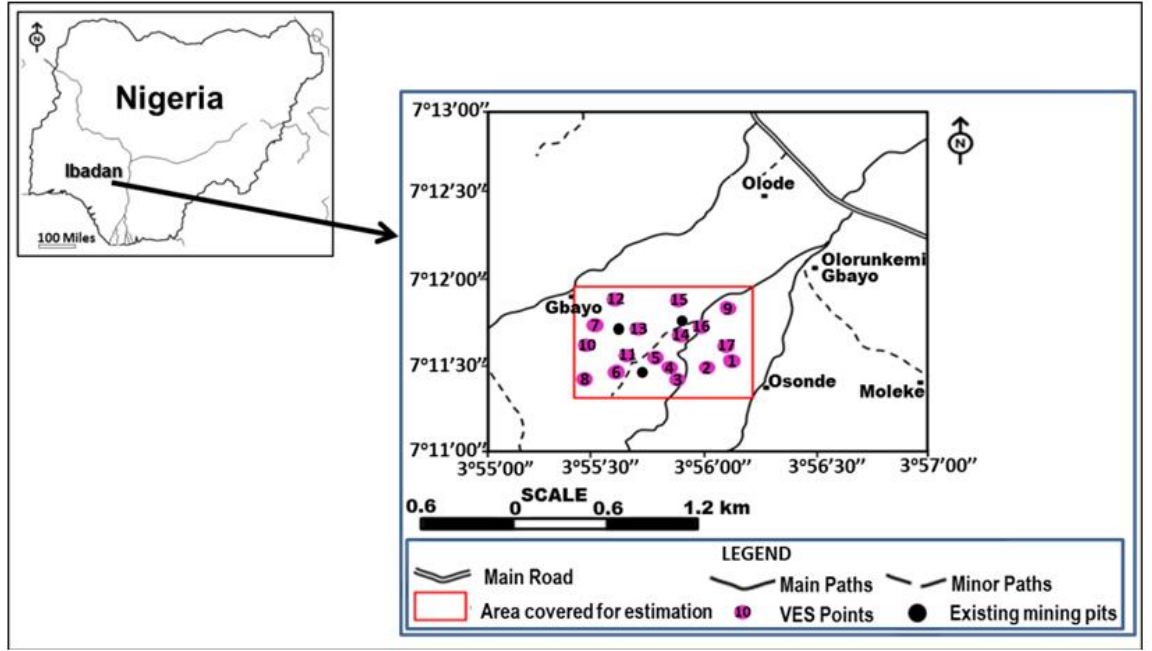

Fig. 2. Location map showing road network and locations of VES points and existing mining pits

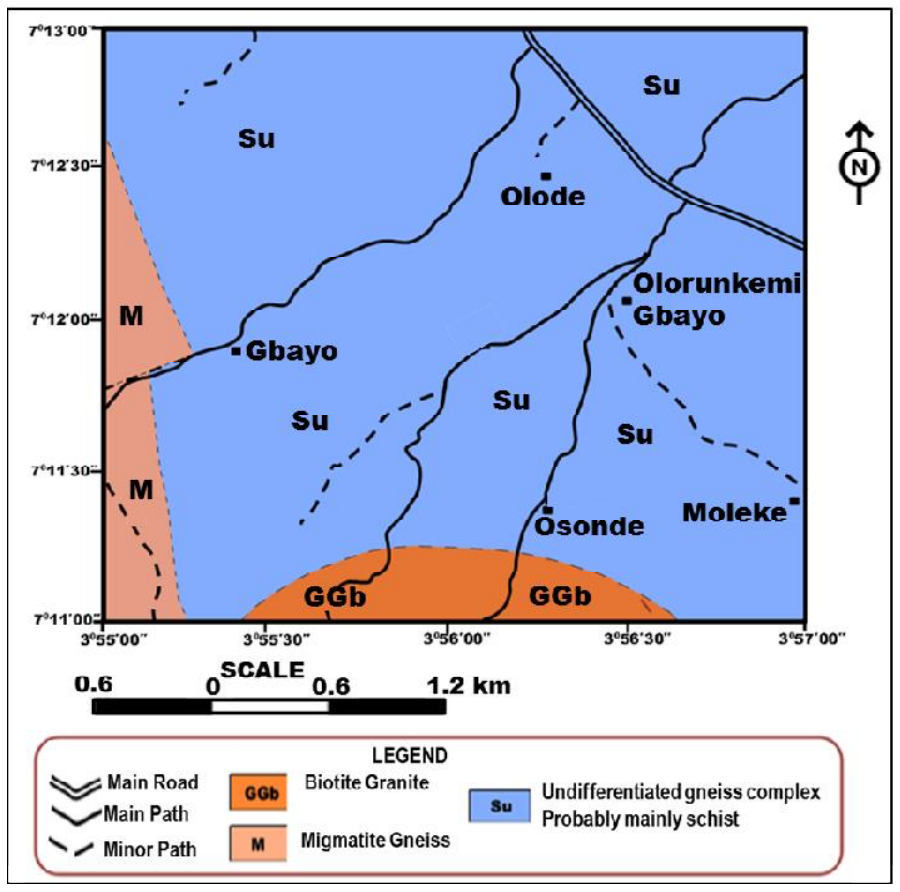

Fig. 3. Geological map of the study area 
resistant-measuring device. A portable $12.5 \mathrm{~V}$ car battery was used as current source while four stainless metal stakes were used as electrodes. A GPS (Global Positioning System) receiver was used to determine the coordinates and elevations of the sounding points. We used four-cycle stacking and set the standard error of measurements to $5 \%$ in the instrument. At each measurement, the resistivity meter displayed resistance and the corresponding RMS (root mean square) error of the reading, which were generally less than $5 \%$ throughout the survey. The recorded resistance values were used to compute apparent resistivity values. The locations of the VES points and existing hand dug wells are shown in Fig. 2. VES were numbered in the order in which soundings were carried out.

The interpretation of VES data involves curve matching technique and computer iteration. The apparent resistivity data obtained from the field was plotted against half of the current electrode spacing $(A B / 2)$ on a log-log scale. The data was first interpreted using conventional partial curve matching and drawing of auxiliary point diagram; results served as input for computer iteration procedure. The prime motive of the VES interpretation method is the determination of the number of layers denoted as " $n$ ", layer thickness in meters denoted by " $h$ ", and layer resistivity in ohm-m denoted by " $\rho$ ". The interpretation of the curve was based on the principle that all points of maxima and minima are indicators of different lithologies. Similarly, where the resistivity values tend to infinity, it is an indication of the fresh basement rock $[7,12,20]$.

Based on the partial curve matching, initial estimates of the resistivities and thicknesses of the various geoelectric layers were obtained. These were used as starting models for a computer-based inversion procedure. The commercially available WINRESIST software was used for the quantitative interpretation. The inversion procedure uses a least-square approach $[15,20,21]$ to minimize the difference between the input data and the theoretically derived curves. Due to handy controls, the WINRESIS was able to choose from a set of equivalent solutions the one that best fit both the geophysical and geological data.

Geoelectric cross sections were constructed based on lateral combination of inverted soundings of the VES results. Next, isopach maps were constructed using results of the resistivity interpretation. The geoelectric cross sections and various maps were constructed using the Surfer 9 software (Golden, Colorado). This program uses various mathematical models to generate maps and cross sections. In this study, Kriging algorithm, using the default setting in the program, was used. Details of the use of Krigging method for gridding and contouring are explained by [22].

\subsubsection{Field mapping}

In addition to geophysical measurements, visual descriptions of outcrops and vertical sections along existing mining pits as well as rock sampling were carried out. Three mining pits were found at the mining site. The pits ranged from $5.4 \mathrm{~m}$ to $11 \mathrm{~m}$ in depths with diameters as wide as $7 \mathrm{~m}$. The pits were dug by artisanal miners that are operating at the site (Fig. 1a). Generally, it was possible to enter the pits for visual lithological descriptions. Special consideration was given to macro-textural features and estimation of relative thickness of the overburden. Measurement of overburden thickness was made for evaluation of depth measurements from VES interpretations. We also estimated relative thickness of exposed pegmatite veins in the existing pits in the mining site (Fig. 1). Relatively fresh pegmatite and other rock samples were collected to determine specific gravity of the rocks. Specific gravity of the rock samples were measured in the laboratory using pycnometer, following ASTM [23]. Geographic sample locations were recorded using a hand-held Garmin e-trex Vista GPS.

\subsubsection{Tonnage calculation}

Based on the geophysical measurement and field observation, probable reserve [11] of the basement rock was estimated assuming a minable depth of $50 \mathrm{~m}$. This depth assumption was based on experience with mining activities generally in the basement complex area of Nigeria [17]. With estimated average overburden thickness from VES; minable thickness was derived by subtracting the overburden thickness from mineable depth, and result was multiplied by the survey area to calculate the volume in place. Finally, the tonnage was derived by multiplying the volume in-place with average specific gravity of the underlying basement rocks [16]. Based on visual observation, relative abundance of pegmatite in the basement complex was estimated. This estimate was incorporated into final calculation to estimate 
probable tonnage of pegmatite in the basement rock of the area. Details of the calculations are summarized in the Appendix.

\section{RESULTS}

Fig. 4 shows examples of the model curves for the VES data. The sounding curves reflect possible presence of three and four geoelectric layers. The three layer models are of $\mathrm{H}\left(\rho_{1}>\right.$ $\left.\rho_{2}<\rho_{3}\right)$ - and $A\left(\rho_{1}<\rho_{2}<\rho_{3}\right)$ - types, whereas the four layer curves are of HA $\left(\rho_{1}>\rho_{2}<\rho_{3}<\rho_{4}\right)$ and $\mathrm{KH}\left(\rho_{1}<\rho_{2}>\rho_{3}<\rho_{4}\right)$ types [20]. The dominant curves are $\mathrm{H}$-types, comprising of 11 out of the 17 interpreted VES curves and are found in various parts of the survey area. The detail interpreted resistivity values, layer thicknesses, layer depths and associated lithology are summarized in Table 1. The first layers in all cases are interpreted as the top soil with model resistivity ranging from $59.5 \mathrm{ohm}-\mathrm{m}$ (VES 10) to 431 ohm-m (VES 1). Generally, the thickness is variable and mostly less than $2 \mathrm{~m}$. Underlying the top soil are lateritic clay, weathered as well as fractured and fresh basement. The depth to the top of the fresh basement rock as obtained from the VES results is interpreted as overburden thickness in the study area.

Fig. 5 shows examples of interpreted crosssections that have been constructed using the results of the VES (Fig. 4). Corresponding sounding points are indicated on each section. These cross-sections are interpretive of twodimensional geometry of the possible geoelectrical layers in the subsurface and have been used to infer possible geometry of subsurface rocks by various authors $[7,24,25]$. Cross-section $A B$, connecting VES 1,2 , and 3 , shows presence of two geoelectric layers within the overburden with the third geoelectric layer being the basement rock. The overburden is thickest, around $7 \mathrm{~m}$, around VES 3 . The deepest geoelectric layers observed by our soundings are interpreted as fresh basement rocks. This fresh basement rocks are of infinite thickness and higher resistivity $[6,7,18]$. Cross sections $C D$ and EF show similar lateral variations in the subsurface layers (Fig. $5 b$ and c), with modeled subsurface being four geoelectrical layers for VES 14 and 17.

Fig. 6 shows overburden thickness map as inferred from the resistivity data interpretation. Results show that overburden thickness is variable, being thickest around VES 1, 2, 8, 10 and 17. Relatively thin overburden occurs in the vicinity of VES $9,12,15$ and 6 . Generally, the thickest overburden is observed in the southeastern part of the surveyed area whereas overburden thickness is lower in the Northern part. The overburden thickness varies from $2.6 \mathrm{~m}$ to $7.9 \mathrm{~m}$, with calculated average value being $5.7 \mathrm{~m}$.
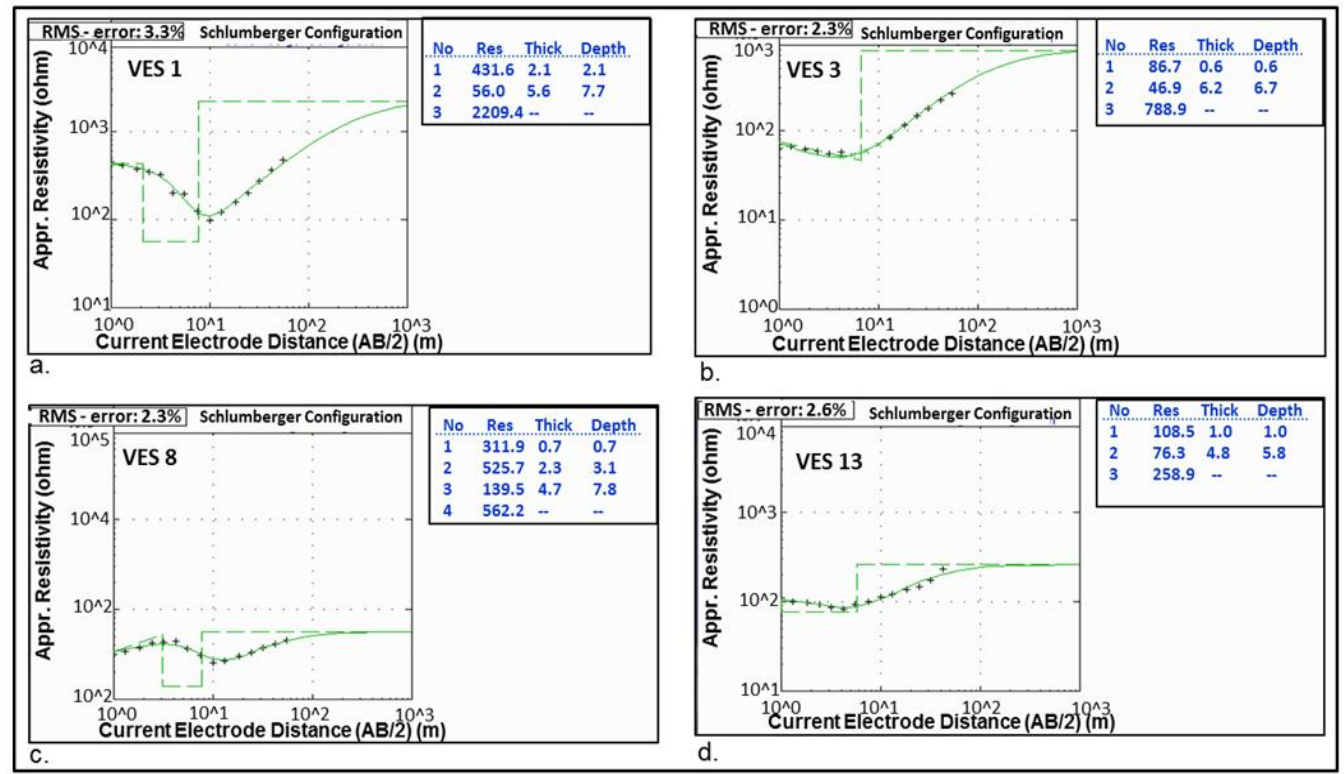

Fig. 4. Examples of model curves from the VES data: (a) VES 1; (b) VES 3; (c) VES 8; and (d) VES 13 
Table 1. Results of computer modeling interpretation of VES curves

\begin{tabular}{|c|c|c|c|c|c|}
\hline Layer & $\begin{array}{l}\text { Resistivity } \\
\text { (ohm-m) }\end{array}$ & $\begin{array}{l}\text { Thickness } \\
\text { (m) }\end{array}$ & $\begin{array}{l}\text { Depth } \\
\text { (m) }\end{array}$ & $\begin{array}{l}\text { Curve } \\
\text { types }\end{array}$ & Probable lithology \\
\hline \multicolumn{6}{|l|}{ VES1 } \\
\hline 1 & 431.6 & 2.1 & 2.1 & \multirow[t]{3}{*}{$\mathrm{H}$} & Top Soil \\
\hline 2 & 56 & 5.6 & 7.7 & & Weathered Basement (clay) \\
\hline 3 & $2,209.40$ & - & - & & Fresh Basement \\
\hline \multicolumn{6}{|l|}{ VES2 } \\
\hline 1 & 137.2 & 1.2 & 1.2 & \multirow[t]{3}{*}{$\mathrm{H}$} & Top Soil \\
\hline 2 & 77.4 & 6.4 & 7.6 & & Weathered Basement (clay) \\
\hline 3 & 583.3 & - & - & & Fresh Basement \\
\hline \multicolumn{6}{|l|}{ VES3 } \\
\hline 1 & 86.7 & 0.6 & 0.6 & \multirow[t]{3}{*}{$\mathrm{H}$} & Top Soil \\
\hline 2 & 46.9 & 6.2 & 6.7 & & Weathered Basement(Clay) \\
\hline 3 & 788.9 & - & - & & Fresh Basement \\
\hline \multicolumn{6}{|l|}{ VES 4} \\
\hline 1 & 173 & 0.9 & 0.9 & \multirow[t]{3}{*}{$\mathrm{H}$} & Top Soil \\
\hline 2 & 96.8 & 3.6 & 3.6 & & Weathered Basement(clay) \\
\hline 3 & 400.4 & - & - & & Fresh Basement \\
\hline \multicolumn{6}{|l|}{ VES 5} \\
\hline 1 & 177.9 & 1 & 1 & \multirow[t]{3}{*}{$\mathrm{H}$} & Top Soil \\
\hline 2 & 80.7 & 5.1 & 6 & & Weathered Basement(clay) \\
\hline 3 & 263.6 & - & - & & Fractured $\backslash$ Fresh Basement \\
\hline \multicolumn{6}{|l|}{ VES 6} \\
\hline 1 & 88.9 & 0.9 & 0.9 & \multirow[t]{3}{*}{$\mathrm{H}$} & Top Soil \\
\hline 2 & 47.3 & 1.7 & 2.6 & & Weathered Basement (clay) \\
\hline 3 & 370.6 & - & - & & Fractured IFresh Basement \\
\hline \multicolumn{6}{|r|}{ 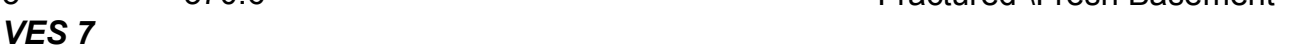 } \\
\hline 1 & 79 & 0.9 & 0.9 & \multirow[t]{3}{*}{ A } & Top Soil \\
\hline 2 & 103.3 & 5.7 & 6.6 & & Weathered Basement (clay) \\
\hline 3 & 267.2 & - & - & & FracturedIFresh Basement \\
\hline \multicolumn{6}{|r|}{ 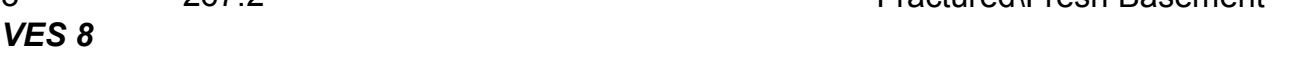 } \\
\hline 1 & 311.9 & 0.7 & 0.7 & \multirow[t]{4}{*}{$\mathrm{AH}$} & Top Soil \\
\hline 2 & 525.7 & 2.3 & 3.1 & & Lateritic Clay \\
\hline 3 & 139.5 & 4.7 & 7.8 & & Weathered Basement (Clay) \\
\hline 4 & 562.2 & - & - & & Fresh Basement \\
\hline \multicolumn{6}{|l|}{ VES 9} \\
\hline 1 & 143.5 & 0.9 & 0.9 & \multirow[t]{3}{*}{$\mathrm{H}$} & Top Soil \\
\hline 2 & 27.8 & 2.2 & 3 & & Weathered Basement (clay) \\
\hline 3 & 310.8 & - & - & & Fractured/ fresh Basement \\
\hline \multicolumn{6}{|c|}{ VES 10} \\
\hline 1 & 59.5 & 0.6 & 0.6 & \multirow[t]{4}{*}{$\mathrm{KH}$} & Top Soil \\
\hline 2 & 191.5 & 1.2 & 1.8 & & Lateritic Clay \\
\hline 3 & 20.8 & 5.3 & 7.1 & & Weathered Basement (clay) \\
\hline 4 & 269 & - & - & & Fresh/Fractured Basement \\
\hline VES 11 & & & & & \\
\hline 1 & 81.8 & 0.5 & 0.5 & $\mathrm{KH}$ & Top Soil \\
\hline 2 & 234.2 & 1.3 & 1.9 & & Lateritic Clay \\
\hline 3 & 15.4 & 3.8 & 5.7 & & Weathered Basement (clay) \\
\hline 4 & 614.1 & $\because$ & - & & Fresh basement \\
\hline VES 12 & & & & & \\
\hline 1 & 121.7 & 1 & 1 & $\mathrm{H}$ & Top Soil \\
\hline 2 & 71 & 2.9 & 3.9 & & Weathered Basement (clay) \\
\hline 3 & 328.9 & - & - & & Fresh Basement \\
\hline
\end{tabular}


Table 1 continued....

\begin{tabular}{|c|c|c|c|c|c|}
\hline \multicolumn{6}{|c|}{ VES 13} \\
\hline 1 & 108.5 & 1 & 1 & \multirow[t]{3}{*}{$\mathrm{H}$} & Top Soil \\
\hline 2 & 76.3 & 4.8 & 4.8 & & Weathered Basement (clay) \\
\hline 3 & 258.9 & - & - & & Fractured IFresh Basement \\
\hline \multicolumn{6}{|r|}{ 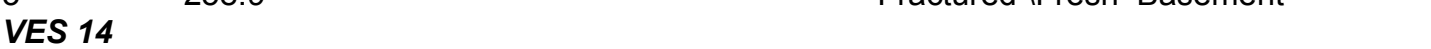 } \\
\hline 1 & 174 & 0.6 & 0.6 & \multirow[t]{4}{*}{$\mathrm{KH}$} & Top Soil \\
\hline 2 & 355.4 & 2.5 & 3.1 & & Lateritic Clay \\
\hline 3 & 157 & 3 & 6 & & Weathered Basement (clay) \\
\hline 4 & 675.2 & - & - & & Fresh Basement \\
\hline \multicolumn{6}{|c|}{ VES 15} \\
\hline 1 & 205.8 & 0.7 & 0.7 & \multirow[t]{4}{*}{$\mathrm{H}$} & Top Soil \\
\hline 2 & 104.4 & 2.3 & 3 & & Weathered Basement (Clay) \\
\hline 3 & 561 & - & - & & Fresh basement \\
\hline \multicolumn{5}{|c|}{ VES 16} & \\
\hline 1 & 161.7 & 1.2 & 1.2 & \multirow[t]{4}{*}{$\mathrm{H}$} & Top Soil \\
\hline 2 & 59.1 & 4 & 5.3 & & Weathered Basement (clay) \\
\hline 3 & 848.7 & - & - & & Fresh Basement \\
\hline \multicolumn{5}{|c|}{ VES 17} & \\
\hline 1 & 208 & 0.5 & 0.5 & \multirow[t]{4}{*}{$\mathrm{KH}$} & Top Soil \\
\hline 2 & 44.5 & 1.2 & 1.7 & & Lateritic Clay \\
\hline 3 & 219.9 & 5.9 & 7.6 & & Weathered Basement(clay) \\
\hline 4 & 145.2 & - & - & & Fresh Basement/ Fractured basement \\
\hline
\end{tabular}

As measured during the field study, overburden thickness varied from about 3 to $7 \mathrm{~m}$. The pegmatite veins occurred as dyke with low dip and strike NNE-SSW cross-cutting other basement rocks (biotite granites and gneiss complexes). Gem-quality aquamarines were found within vugs and cavities in the pegmatite (Fig. 1b). The thickness of the aquamarine bearing pegmatite was around $5 \mathrm{~m}$ in width, and was encountered in the three existing pits that were studied at the mining site. Based on visual observation, we estimated that pegmatite constitute $0.5 \%$ of the basement rocks. Also, average specific gravity was determined to be 2.7 .

With probable overburden thickness determined from field resistivity survey, probable reserve was estimated by relating geophysical results with field observation. The details of reserve calculation using results from geophysical measurements and field observation are shown in the Appendix. Probable tonnage for the basement rock, assuming a minable depth of 50 $\mathrm{m}$ is estimated as $1.95 \times 10^{8}$ tons, with probable reserve for pegmatite in the host rock being about $9.75 \times 10^{5}$ tons.

\section{DISCUSSION}

The present study has contributed to better understanding of subsurface geoelectric distribution, overburden thickness and possible reserve potential of the basement rock in the study area. The three- and four- layer model curves obtained from the VES interpretations together with resistivity values are consistent with results from previous VES surveys in other areas in the basement complex of Nigeria as reported in the literature $[5,7,18,26]$. For example, the predominance of three-layer $\mathrm{H}$-type curves in the study area agrees with results of [7] and [25], who reported $18 \mathrm{H}$-type curves out of 25 , and 16 H-type curves out of 22 sounding points, respectively, in different parts of the basement complex in southwestern Nigeria.

The VES-derived isopach map enabled estimation of possible overburden thickness within the study area with the thickest overburden occurring in the southern part and lower overburden thicknesses in the north (Fig. 4). As shown by [8], overburden thickness significantly influences method of excavation; the thicker the overburden the higher the cost of excavation. Thus, whereas simple manual shoveling, as it is currently being practiced at the mining site may still be useful for relatively thin overburden in the northern part, mechanized approach involving heavy equipment may be necessary for relatively thick overburden in the southern part of the study area. Generally, the estimated overburden thickness range of between 2.6 to $7.7 \mathrm{~m}$ is consistent with overburden thickness of 5.8 to $6.72 \mathrm{~m}$ obtained by [27], using magnetic and electrical resistivity 
methods in the study area. Generally, considering the shallow overburden thickness around the vicinity of rock outcrops, it is expected that less material will be excavated before actual mining of rock and mineral deposits is undertaken at the site.

The tonnage of the rock as estimated shows significant quantity of the rock can be mined for economic returns to the miners and the government. At a projected production rate of 5,000 tons per day, the basement rock reserve is expected to last for over 108 years. The rock as it is, is largely fresh, and should be suitable for civil and engineering construction. The general accessibility and closeness to Ibadan metropolis is an advantage on the cost of transportation. Results also indicate that tonnage reserve of pegmatites could be significant at Olode-Gbayo mining site. Thus, with systematic exploration and mining programme, there is high potential of locating qualitative gem-bearing pegmatite rocks. In particular, presence of medium grained mica, feldspar and quartz in the pegmatite samples that were collected at the site (Fig. 1b) can serve as a guide to locating gem-quality aquamarine [2].

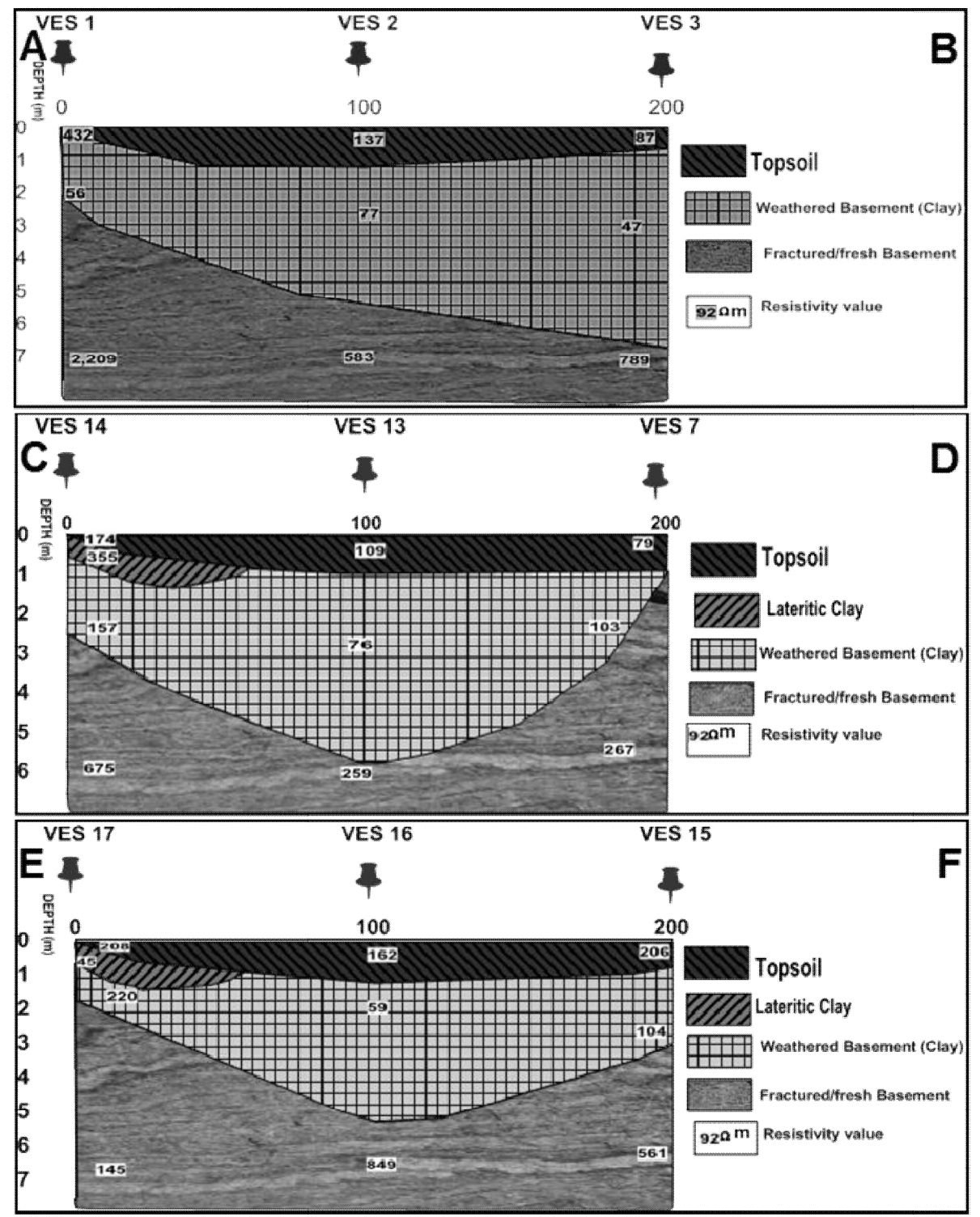

Fig. 5. Examples of geoelectric cross sections from VES data 


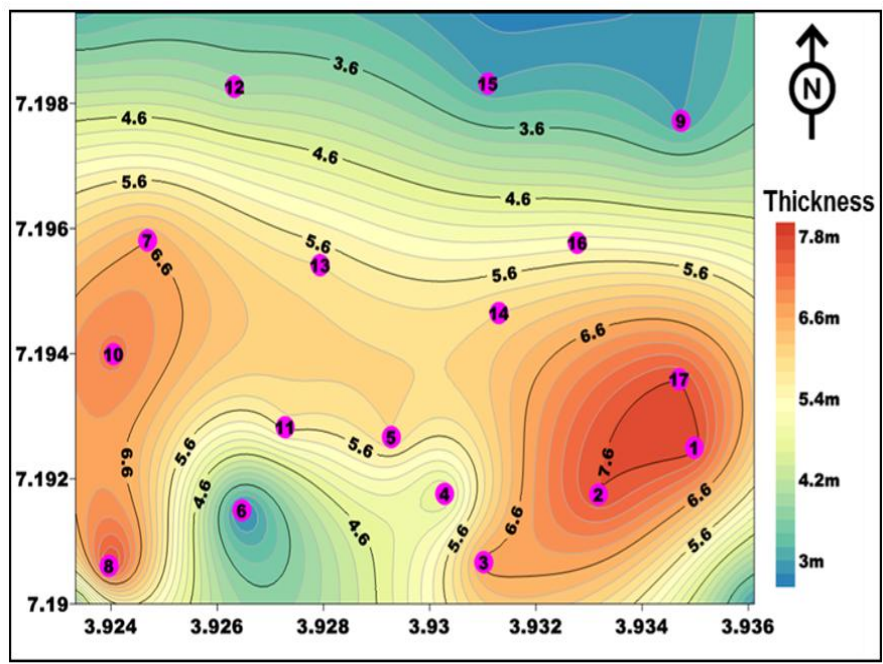

Fig. 6. 2D Isopach map of the overburden thicknesses as inferred from the resistivity data interpretation

The use and evaluation of VES method in estimating depth profiles have been the focus of several studies $[5,7,18,20,25]$, where results have shown that relatively accurate measure of subsurface thickness can be obtained using this geophysical method. The present study is very well aligned with these previous studies as the resistivity-derived overburden thicknesses are consistent with measured thicknesses from the mining pits. Although, the present approach to tonnage estimation is very preliminary, it offers great potential for estimating overburden thickness, where results can be extended in estimating reserves, thereby improving effective overall assessment and management of mining activities at quarrying sites.

\section{CONCLUSION}

Geophysical investigation together with visual rock descriptions have helped to better understand subsurface geology in the study area. The subsurface layers are found to comprise of the top lateritic soil, weathered layer, fractured and weathered basement. The results of the VES were extended to estimate possible tonnage potential of the basement rock. The tonnage of the rock as estimated shows significant quantity of rocks can be mined for economic returns to the miners and the government. The present approach to tonnage potential estimation is by all means preliminary, as more accurate tonnage estimation will require detail and extensive studies. Also, several more rigorous methods of tonnage potential estimation abound in the literature. Nonetheless, the geophysical method as applied in this study can be used for easier estimation of overburden thickness to guide excavation methods and also for optimal and economic planning of activities at mining sites. Generally, further geophysical and geological studies are recommended for detail mapping of mineral occurrences. This will enable better estimation of grades and tonnages for optimal mining and exploitation of minerals and basement rocks in Olode-Gbayo and its environment.

\section{COMPETING INTERESTS}

Authors have declared that no competing interests exist.

\section{REFERENCES}

1. Okunlola OA, Ogedengbe $O$. Investment potential of gemstone occurrences in southwestern Nigeria. In: Eluze AA, editor. Prospect for Investment in Mineral Resources of Southwestern Nigeria. Nigerian Mining and Geosciences Society; 1990.

2. Okunlola OA. Metallogeny of tantalumniobium mineralization of Precambrian pegmatite of Nigeria. Mineral Wealth. 2005;104(2):38-50.

3. Obaje NG. Geology and mineral resources of Nigeria. Lecture Notes in Earth Sciences. Springer, New York (NY); 2009. 
4. Acworth RI. The development of crystalline basement aquifers in a tropical environment. Quart. J. Eng. Geol. Hydrogeol. 1987;20:265-272.

5. Olorunfemi MO, Fasuyi SA. Aquifer types and the geoelectric hydrogeologic characteristics of parts of the central basement terrain of Nigeria, Niger state. J. Afr. Earth Sci. (and Mid. East). 1993;6:309317.

6. Olayinka Al. Geophysical siting of boreholes in crystalline basement areas of Africa. J. Earth Sci. (and Mid.East). 1992; 14:197-207.

7. Abudulawal L, Amidu SA, Apanpa KA, Adeagbo OA, Akinbiyi OA. Geophysical investigation of subsurface water of Erunmu and its environs, southwestern Nigeria using electrical resistivity method. J. Appl. Sci. 2015;15:741-751.

DOI: $10.3923 /$ jas

8. Bell FG. Engineering geology. $2^{\text {nd }}$ Edition. New York: Elsevier; 2006

9. Ayinla FM. Geology and mineral resources of Oyo State, Southwestern Nigeria. J. Sci. Res. and Rep. 2014;3(21):2718-2731.

10. Downing BC, Giroux G., Estimation of a waste rock $A R D$, block model for the Windy Craggy massive sulfide deposit, Northwestern British Columbia. Explor. Min. Geol. 1993;2(3):203-215.

11. Wellmer FW, Dalheimaer $M$, Wagner $M$. Economic evaluations in exploration. London: Springer Publishing; 2008.

12. Telford WM, Geldart LP, Sheriff RE. Applied Geophysics. $2^{\text {nd }}$ Ed. Cambridge University Press; 1990.

13. Draskovits $P$, Simon A. Application of geoelectric methods using buried electrodes in exploration and mining: Geophys. Prosp. 1992;40:573-586.

14. Amidu SA, Olayinka Al. Environmental assessment of sewage disposal systems using 2D electrical-resistivity imaging and geochemical analysis: A case study from Ibadan, southwestern Nigeria: Envir. Eng. Geosci. 2006;12:261-272.

15. Amidu SA, Dunbar JA. An evaluation of the electrical-resistivity method for waterreservoir salinity studies. Geophys. 2008; 73:G39-G49.

16. Ehinola OA, Oladunjoye MA, Gbadamosi TO. Chemical composition, geophysical mapping and reserve estimation of clay deposit from parts of Southwestern Nigeria. J. Geol. Min. Res. 2009;1(3): 57-66.
17. Bale RB, Bayewu OO, Folorunso IO, Oloruntola MO. Estimation of reserveoverburden ratio of a proposed quarry site using resistivity survey: $A$ case study of Ajebo, near Abeokuta, southwestern Nigeria. J. Appl. Sci. Res. 2011;7(10): 1402-1410.

18. Olayinka Al, Amidu SA, Oladunjoye MA. Use of electromagnetic profiling and resistivity sounding for groundwater exploration in the crystalline basement area of Igbeti, Southwestern Nigeria. Glob. J. Geol. Sci. 2004;2:243-253.

19. Rahaman MA. Review of the basement geology of South-Western Nigeria. In: Kogbe CA, editor. Geology of Nigeria, $2^{\text {nd }}$ Ed. Lagos: Elizabethan Publishers; 1976

20. Zohdy AAR. A new method for the automatic interpretation of Schlumberger and Wenner sounding curves. Geophys. 1989;54:245-253.

21. Loke MH, Barker RD. Rapid least-squares inversion of apparent resistivity pseudosections by a quasi-Newton method. Geophys. Prospect. 1996;44:131152.

22. Oliver MA, Webster R. Kriging: A method of interpolation for geographical information systems. Int. J. Geogr. Inform. Syst. 1990;4:313-332.

23. ASTMC914-95. Standard test method for bulk density and volume of solid refractories by wax immersion. ASTM International; 2004.

24. Mbonu, P, Ebeniro J, Ofoegbu C, Ekine A. Geoelectric sounding for the determination of aquifer characteristics in parts of the Umuahia area of Nigeria. Geophys. 1991;56:284-291.

25. Oladunjoye MA, Akanji AO, Akingbesote OT. Groundwater exploration in AlakutaAwotan area of Ibadan, southwestern Nigeria. J. Geol. Geosci. 2013;2:124.

DOI: 10.4172/2329-6755.1000124

26. Ajayi O, Adegoke-Anthony CW. Groundwater prospects in the basement complex rocks of Southwestern Nigeria. J. Afr. Earth Sci. (Middle East). 1988;7:227235.

27. Ojo AO, Omotoso TO, Adekunle OJ. Determination of location and depth of mineral rocks at Olode village in Ibadan, Oyo State, Nigeria, using geophysical methods. J. Geol. Res; 2014. Available:http://dx.doi.org/10.1155/2014/30 $\underline{6862}$ 


\section{APPENDIX}

\section{Calculation of Probable Reserve Estimate}

Based on the geophysical parameters, the reserve was estimated as follows:

Area extent

Length of the area

Breadth

Area extent

Probable Reserve Volume

Average Bed rock thickness

Average Bed rock thickness

Probable Reserve Volume
$=$ length $\mathrm{x}$ breath of the area of investigation

$=1560 \mathrm{~m}$

$=1050 \mathrm{~m}$

$=1560 \mathrm{~m} \times 1050 \mathrm{~m}=1,638,000 \mathrm{~m}^{2}$

$=$ Area extent $x$ Average bedrock thickness

= Estimated depth of $50 \mathrm{~m}-$ Average overburden thickness

$=50 \mathrm{~m}-5.7 \mathrm{~m}=44.3 \mathrm{~m}$

$=1,638,000 \mathrm{~m}^{2} \times 44.3 \mathrm{~m}=72,563,400 \mathrm{~m}^{3}$

Probable Volume of the rock deposit at estimated depth of $50 \mathrm{~m}$ allowing $5.7 \mathrm{~m}$ as the average thickness of overburden $=72,563,400 \mathrm{~m}^{3}$

Hence:

Potential Tonnage of rock = Probable Reserve Volume $X$ specific gravity (tons) $=72,563,400 \mathrm{~m}^{3} \times 2.7=195,921,180$ tons

where 2.7 is specific gravity

Probable tonnage of pegmatite in the basement rock $=0.5 \% \times 195,921,180=979,605.9$ tons

(Value of $0.5 \%$ being relative proportion of pegmatite based on field mapping)

(c) 2017 Abudulawal et al.; This is an Open Access article distributed under the terms of the Creative Commons Attribution License (http://creativecommons.org/licenses/by/4.0), which permits unrestricted use, distribution, and reproduction in any medium, provided the original work is properly cited.

Peer-review history:

The peer review history for this paper can be accessed here: http://sciencedomain.org/review-history/19131 